\title{
The Holocene
}

http://hol.sagepub.com/

New insights into paleoenvironmental changes in Laguna Potrok Aike, southern Patagonia, since the Late Pleistocene: The PASADO multiproxy record

Cristina Recasens, Daniel Ariztegui, Catalina Gebhardt, Claudia Gogorza, Torsten Haberzettl, Annette Hahn, Pierre

Kliem, Agathe Lisé-Pronovost, Andreas Lücke, Nora Maidana, Christoph Mayr, Christian Ohlendorf, Frank Schäbitz, Guillaume St-Onge, Michael Wille, Bernd Zolitschka and Science Team

The Holocene 2012 22: 1323 originally published online 14 December 2011

DOI: $10.1177 / 0959683611429833$

The online version of this article can be found at:

http://hol.sagepub.com/content/22/11/1323

\author{
Published by: \\ (4)SAGE \\ http://www.sagepublications.com
}

Additional services and information for The Holocene can be found at:

Email Alerts: http://hol.sagepub.com/cgi/alerts

Subscriptions: http://hol.sagepub.com/subscriptions

Reprints: http://www.sagepub.com/journalsReprints.nav

Permissions: http://www.sagepub.com/journalsPermissions.nav

Citations: http://hol.sagepub.com/content/22/11/1323.refs.html

>> Version of Record - Oct 17, 2012

OnlineFirst Version of Record - Dec 14, 2011

What is This? 


\title{
New insights into paleoenvironmental changes in Laguna Potrok Aike, southern Patagonia, since the Late Pleistocene: The PASADO multiproxy record
}

\author{
Cristina Recasens,' Daniel Ariztegui,' Catalina Gebhardt, ${ }^{2}$ \\ Claudia Gogorza, ${ }^{3}$ Torsten Haberzettl, ${ }^{4}$ Annette Hahn, ${ }^{5}$ \\ Pierre Kliem, ${ }^{5}$ Agathe Lisé-Pronovost, ${ }^{6}$ Andreas Lücke, ${ }^{7}$ \\ Nora Maidana, ${ }^{8}$ Christoph Mayr, ${ }^{9}$ Christian Ohlendorf, ${ }^{5}$ \\ Frank Schäbitz, ${ }^{10}$ Guillaume St-Onge, ${ }^{6}$ Michael Wille, ${ }^{10}$ \\ Bernd Zolitschka ${ }^{5}$ and the PASADO Science Team ${ }^{\prime \prime}$
}

\begin{abstract}
A series of long sediment cores was retrieved from Laguna Potrok Aike, Southern Patagonia, within the framework of PASADO (Potrok Aike Maar Lake Sediment Archive Drilling Project), an ICDP (International Continental Scientific Drilling Program) lake drilling project. This maar lake, located at $52^{\circ} \mathrm{S}, 70^{\circ} \mathrm{W}$ in the Province of Santa Cruz (Argentina), in the southernmost continental area of the world, is one of the few permanent lakes in the region, providing a unique continuous paleoclimatic and paleoecological lacustrine record for the last glacial cycle. Previous multiproxy studies of this site have characterized the environmental history of these dry lands in the Patagonian Steppe for the last 16 cal. ka BP. This new series of sediment cores provides a much longer record of climate variability in Southern Patagonia since $51.3 \mathrm{cal}$. ka BP. Using a multiproxy strategy, a set of samples (mostly from core catcher material) was analyzed for physical properties, rock magnetism, geochemistry, CNS elemental analysis, stable isotopes, pollen and diatoms. This preliminary multiproxy limnogeological interpretation sheds new light on the regional Pleistocene and Holocene environmental history, revealing lake-level variations through time and identifying time windows of interest where higher resolution analyses will be carried out.
\end{abstract}

\section{Keywords}

diatoms, geochemistry, lacustrine sediments, physical properties, pollen, rock magnetism, stable isotopes

Received 2I February 20I I; revised manuscript accepted I October 20II

\section{Introduction}

High-resolution paleolimnological studies in southern Patagonia are relatively scarce though essential for understanding paleoclimatic evolution of South America and its relationship to both Northern Hemisphere and Antarctic climate variability (e.g. Ariztegui et al., 2008). Previous paleolimnological investigations in southern Patagonia include multiproxy studies of Lago Cardiel, $49^{\circ} \mathrm{S}$ (Gilli et al., 2001; Markgraf et al., 2003); Laguna Azul, $52^{\circ} \mathrm{S}$ (Mayr et al., 2005); Laguna Las Vizcachas $50^{\circ} \mathrm{S}$ (Fey et al., 2009); Lago Fagnano, $55^{\circ} \mathrm{S}$ (Moy et al., 2011; Waldmann et al., 2009) and Laguna Potrok Aike, $52^{\circ} \mathrm{S}$ (Haberzettl et al., 2005, 2006, 2007, 2009; Mayr et al., 2007a, 2009; Wille et al., 2007) which is the object of this study. These investigations illustrate the power of multiproxy paleolimnological research in tackling outstanding questions dealing with the late-Quaternary environmental evolution of southernmost South America and their comparison with marine and Antarctic studies. The latter will allow a better understanding of the Southern Hemispheric paleoclimate trends and their input into the global climate system.

An international research group participated in 2008 in the 'Potrok Aike Maar Lake Sediment Archive Drilling Project' (PASADO, expedition No. 5022) within the framework of the ICDP (International Continental Scientific Drilling Program).
During this drilling campaign, more than $500 \mathrm{~m}$ of sediment cores were retrieved from the center of Laguna Potrok Aike. Such a long record is unique for this area and is a very valuable tool to better

'University of Geneva, Switzerland

${ }^{2}$ Alfred Wegener Institute for Polar and Marine Research, Germany

${ }^{3}$ Universidad Nacional del Centro de la Provincia de Buenos Aires, Argentina

${ }^{4}$ Friedrich-Schiller University of Jena, Germany

${ }^{5}$ University of Bremen, Germany

${ }^{6}$ Université du Québec à Rimouski (UQAR), and GEOTOP Research Centre, Canada

${ }^{7}$ Research Center Jülich, Germany

${ }^{8}$ University of Buenos Aires, Argentina

${ }^{9}$ Friedrich-Alexander-University Erlangen-Nuremberg, and University of Munich, Germany

${ }^{10}$ University of Cologne, Germany

"List of members available from http://www.icdp-online.org/ front_content.php?idcat $=\mid 494$

\section{Corresponding author:}

Cristina Recasens, Université de Genève, Rue des Maraichers I3,

Geneva I205, Switzerland.

Email: cristina.recasens@unige.ch 


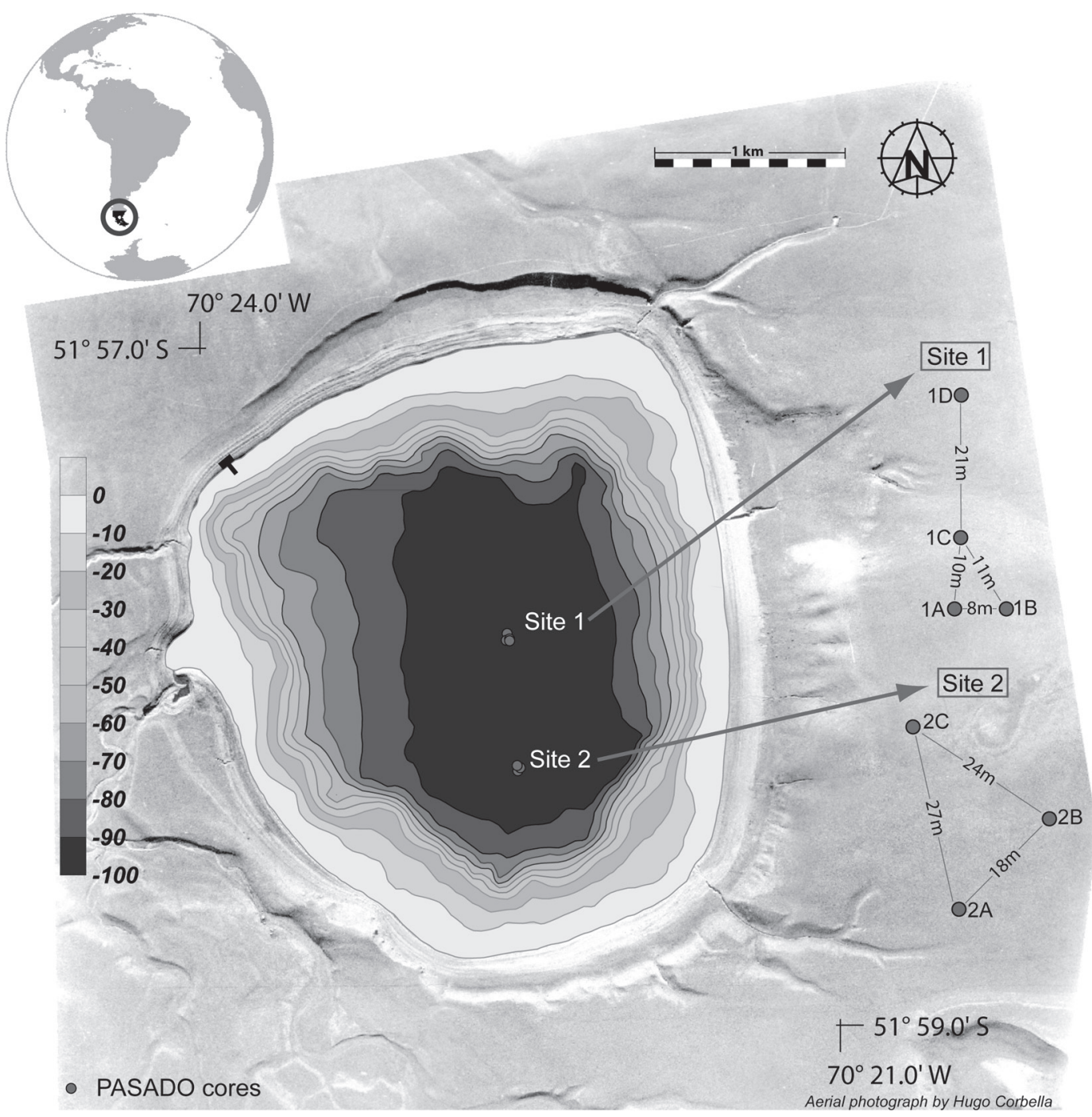

Figure I. Bathymetric map of Laguna Potrok Aike with a $10 \mathrm{~m}$ contour interval superimposed to an aerial photograph showing the position of the drilling sites and the relative position of the different cores at each site. Insert on the left shows the geographical location on a world map (modified from Ohlendorf et al., 20I I).

characterize climate and environmental changes since the Late Pleistocene. In this contribution we present preliminary multiproxy data (mostly from core catcher samples) to provide a first hint on the different processes ruling sedimentation, magnetic grains, organic matter and pollen provenance, as well as diatom assemblages. These data permit to outline a preliminary interpretation of environmental changes in the lake and its catchment area.

\section{Geographical and climatic setting}

Laguna Potrok Aike is located at $52^{\circ} \mathrm{S}, 70^{\circ} \mathrm{W}$ in the province of Santa Cruz, Argentina. This 770 ka old maar located in the Pali Aike Volcanic Field is one of the few permanent lakes in this steppe environment, providing a continuous sedimentary record over an extended time span in this southernmost continental area of the world (Zolitschka et al., 2006). Laguna Potrok Aike has a maximum diameter of $3.5 \mathrm{~km}$ and water depth reaches $100 \mathrm{~m}$ in the center of the basin (Figure 1). The bowl shaped bathymetry reveals evidence of an older lake level low stand at $-35 \mathrm{~m}$ water depth (Anselmetti et al., 2009; Haberzettl et al., 2008). The lake receives only occasional inflow through several canyons and currently has no surface outflow (Zolitschka et al., 2006). Its location in the dry Patagonian Steppe, characterized by the rain shadow effect of the
Andes, results in less than $300 \mathrm{~mm}$ of precipitation per year (Mayr et al., 2007b). Climate in the area is characterized by strong westerly winds, constituting more than $50 \%$ of the wind directions and reaching mean annual wind speeds of $4.6 \mathrm{~m} / \mathrm{s}$ in summer (Mayr et al., 2007a, b). Such strong winds prevent a stratification of the lake water body, thus leading to polymictic conditions, and impeding the development of an ice cover in winter. Both subaerial and submerged paleoshorelines are witnesses of significant lake level variations in the past. A summary of the related hydrological dynamics based on these paleoshoreline reconstructions (Anselmetti et al., 2009) documents a stepwise lake-level rise since $6.8 \mathrm{cal}$. ka BP and reconstructs the onset of drift deposits (and thus lake currents), variations in sedimentation rates, the occurrence of lateral massflow events and lake-level fluctuations. This is supported by sedimentological analyses of a $19 \mathrm{~m}$ long piston core recording environmental and climatic variations for the past $16 \mathrm{cal}$. ka BP (Haberzettl et al., 2007; Mayr et al., 2009).

\section{Sampling and analytical methods}

Drilling operations and sampling

A total of $533 \mathrm{~m}$ of sediment cores was recovered from Laguna Potrok Aike at two different sites during drilling operations in the 
austral late winter/spring of 2008 (Zolitschka et al., 2009). Coring was achieved with the GLAD800 coring system, operated by DOSECC (Consortium for Drilling, Observation and Sampling of the Earth's Continental Crust) using mainly a Hydraulic Piston Corer (HPC) tool. Drill Site 1, located in the center of the lake, and drill Site 2, positioned about $700 \mathrm{~m}$ towards the southern shore, are shown in Figure 1. Four holes were drilled at Site 1 with an average core recovery of $92.1 \%$ and a maximum core depth of $100.4 \mathrm{~m}$ below lake floor (b.1.f.). Three holes were drilled at Site 2 with an average core recovery of $98.8 \%$ and a maximum core depth of $101.5 \mathrm{~m}$ b.l.f. Core lengths and the corresponding recovery rates are summarized in detail in Zolitschka et al. (2009: table 1). Every core run shot into the sediment was approximately $3 \mathrm{~m}$ long, and immediately after recovery a core catcher sample (if possible) was collected. A total of 178 core catcher samples (CC) - 107 and 71 samples for Sites 1 and 2, respectively - was recovered from the seven drill holes. Sample nomenclature will be as follows: PASADO expedition No. (5022) followed by site, hole (1D), run (4) and section (CC for core catcher), e.g. 5022-1D-4CC.

\section{On-site field laboratory analyses}

In order to get first-hand data as soon as possible, an on-site field laboratory was set up next to the lake during the drilling campaign. The exact length and the weight of each core section were determined in order to calculate mean wet bulk densities for each core section. From these values, sediment porosities were determined following the approach of Paull et al. (1996) and assuming a water density of $1.00 \mathrm{~g} / \mathrm{cm}^{3}\left(4^{\circ} \mathrm{C}, 3000 \mu \mathrm{S} / \mathrm{cm}\right)$ and a mean grain density of $2.60 \mathrm{~g} / \mathrm{cm}^{3}$. Each core section was scanned with a Geotek multisensor core logger (Geotek Ltd, UK) to obtain magnetic susceptibility data. The 178 core catcher samples were described and analyzed respecting a standard protocol. The following parameters were measured with ion-selective electrodes immediately after core recovery: $\mathrm{pH}, \mathrm{Cl}^{-}, \mathrm{Ca}^{2+}$, electrical conductivity (all in sediment suspension), water content and dry density (Zolitschka et al., 2009; Ohlendorf et al., 2001). $\mathrm{Cl}^{-}$, conductivity and $\mathrm{pH}$ measurements were performed in a suspension produced by mixing of 25 $\mathrm{ml}$ deionized water with $1 \mathrm{~cm}^{3}$ subsamples taken from the core catchers using syringes. After shaking and 30 min reaction time, the suspended particles were allowed to settle down and measurements were conducted in the clear supernatant solution at $20^{\circ} \mathrm{C}$. For the measurement of $\mathrm{Ca}^{2+}$ a second solution was produced using $1 \mathrm{~mol} / \mathrm{l} \mathrm{HCl}$ instead of deionized water. After reaction and neutralization with $1 \mathrm{~mol} / \mathrm{l} \mathrm{NaOH}$ measurements were conducted in a similar manner.

\section{Off-site laboratory analyses}

In addition to the on-site analyses, the core catcher material was subsampled for more detailed investigations to be carried out in the respective home laboratories which include grain size characterization, rock magnetics, bulk organic geochemistry, stable isotopes, pollen and diatom analyses. In this article the results of the analyses on the CC samples from cores 5022-1A, -1D, -2A and $-2 \mathrm{C}$ are presented. Grain size distribution was measured on the $\mathrm{CC}$ samples from holes $1 \mathrm{D}$ and $2 \mathrm{C}$ using laser diffraction (CILAS 1180). Ultrasonic pre-treatment ensured an adequate homogenization of the sample as well as a good dispersion of the suspension. The measurement range of the CILAS 1180 is from 0.04 to $2000 \mu \mathrm{m}$, thus samples containing grains larger than $2 \mathrm{~mm}$ (5022-1D-25CC, 5022-2C-29CC and -33CC) were not measured. In the lithological profile, these samples were considered as gravelbearing beds.
Rock magnetic data from the $\mathrm{CC}$ samples provide preliminary information both on magnetic mineralogy and grain size. The hysteresis loop is a unique manifestation of ferromagnetic sensu lato material, and the shape of the loop reflects the magnetic mineralogy, the domain state and the magnetic particle size, shape and interaction (Tauxe et al., 1996). The hysteresis loops and the derived properties including the bulk coercive force $(\mathrm{Hc})$, the remanent coercive force (Hcr), the saturation magnetization (Ms) and the saturation remanence $(\mathrm{Mr})$ were measured for all $\mathrm{CC}$ samples of holes 1D and 2A. In addition, the isothermal remanent magnetization (IRM) acquisition curve was obtained for selected samples (5022-1D-1CC, -9CC, -16CC, -22CC, -27CC and 5022$2 \mathrm{~A}-2 \mathrm{CC},-6 \mathrm{CC},-10 \mathrm{CC},-18 \mathrm{CC},-21 \mathrm{CC},-23 \mathrm{CC},-27 \mathrm{CC}$ and $-28 \mathrm{CC}$ ) using an alternating gradient force magnetometer (Princeton Measurement Corporation model MicroMag 2900 AGM) in order to determine the mineralogy of the magnetic carriers. To obtain additional information and to investigate possible chemical changes of magnetic minerals the high-temperature dependence of magnetic susceptibility was analyzed in ambient atmosphere on all CC samples from 5022-2A and on selected samples from 5022-1D (5022-1D-1CC, -9CC, -16CC, - 22CC and -27CC) from $50^{\circ} \mathrm{C}$ to $700^{\circ} \mathrm{C}$ at $5^{\circ} \mathrm{C}$ intervals using a MS2 X/T Bartington system. The measurements were conducted with the ceramic crucible filled at full capacity with $c .3 \mathrm{~g}$ dried sediment.

Core catcher samples from cores 5022-1A, -1D, -2A and -2C were analyzed for bulk organic geochemistry and stable isotopes of the organic fraction. Prior to the conventional measurements of element concentrations, samples were freeze-dried and ground for homogenization. The concentrations of Total Carbon (TC) and Total Nitrogen (TN) in the sediment were determined with a CNS elemental analyzer (EuroEA3000, EuroVector). Samples for the measurement of Total Organic Carbon (TOC) were pre-treated with $3 \%$ and $20 \% \mathrm{HCl}$ at a temperature of $80^{\circ} \mathrm{C}$ to remove carbonates and subsequently analyzed with the same device. Values for Total Inorganic Carbon (TIC) concentrations resulted from the subtraction of TOC from the TC values. Values for $\mathrm{C} / \mathrm{N}$ result from the ratio between TOC and TN.

For stable isotope analyses, freeze-dried samples were cautiously homogenized and sieved at $200 \mu \mathrm{m}$ to remove coarse organic debris. The aliquot $(<200 \mu \mathrm{m})$ for carbon isotope analyses was pre-treated with hydrochloric acid $(5 \%)$ in a water bath $\left(50^{\circ} \mathrm{C}\right)$ for several hours to remove carbonates and washed with distilled water to remove reagents. Nitrogen isotope analysis was performed on the small sediment fraction $(<200 \mu \mathrm{m})$ without further pre-treatment. Isotope ratios were determined with an IsoPrime ${ }^{\mathrm{TM}}$ (GV Instruments, $\mathrm{UK}$ ) continuous flow isotope ratio mass spectrometer coupled to an elemental analyser (EuroEA3000, EuroVector). Isotope ratios are expressed in the $\delta$-notation, where $\delta=\left(R_{\mathrm{s}} / R_{\mathrm{st}}-1\right) \times 1000$, with $R_{\mathrm{s}}$ and $R_{\mathrm{st}}$ as isotope ratios of the sample and the standards versus VPDB for carbon and air for nitrogen, respectively. Calibration of raw values was performed using a multiple standards model. Analytical precision (one standard deviation) was better than $0.10 \%$ and $0.15 \%$ for organic carbon and nitrogen stable isotope ratios, respectively.

Pollen samples were treated following the method established for Laguna Potrok Aike samples during the former SALSA project (Wille et al., 2007). Sixty-seven pollen samples from core catchers (33 samples in 5022-1D and 34 samples in 5022-2C) were analyzed. The pollen sum is based on all pollen taxa excluding Nothofagus as major element of distant Andean Forest, aquatics, spores, algae or other detected microfossil remains. Percentages are based on this pollen sum. Owing to low pollen concentrations, no sample in hole $1 \mathrm{D}$ and only eight samples in hole $2 \mathrm{C}$ reached a pollen sum of 300 grains. In hole $1 \mathrm{D}, 14$ samples were free of pollen, whereas in hole $2 \mathrm{C}$ only one sample contained no pollen. All 


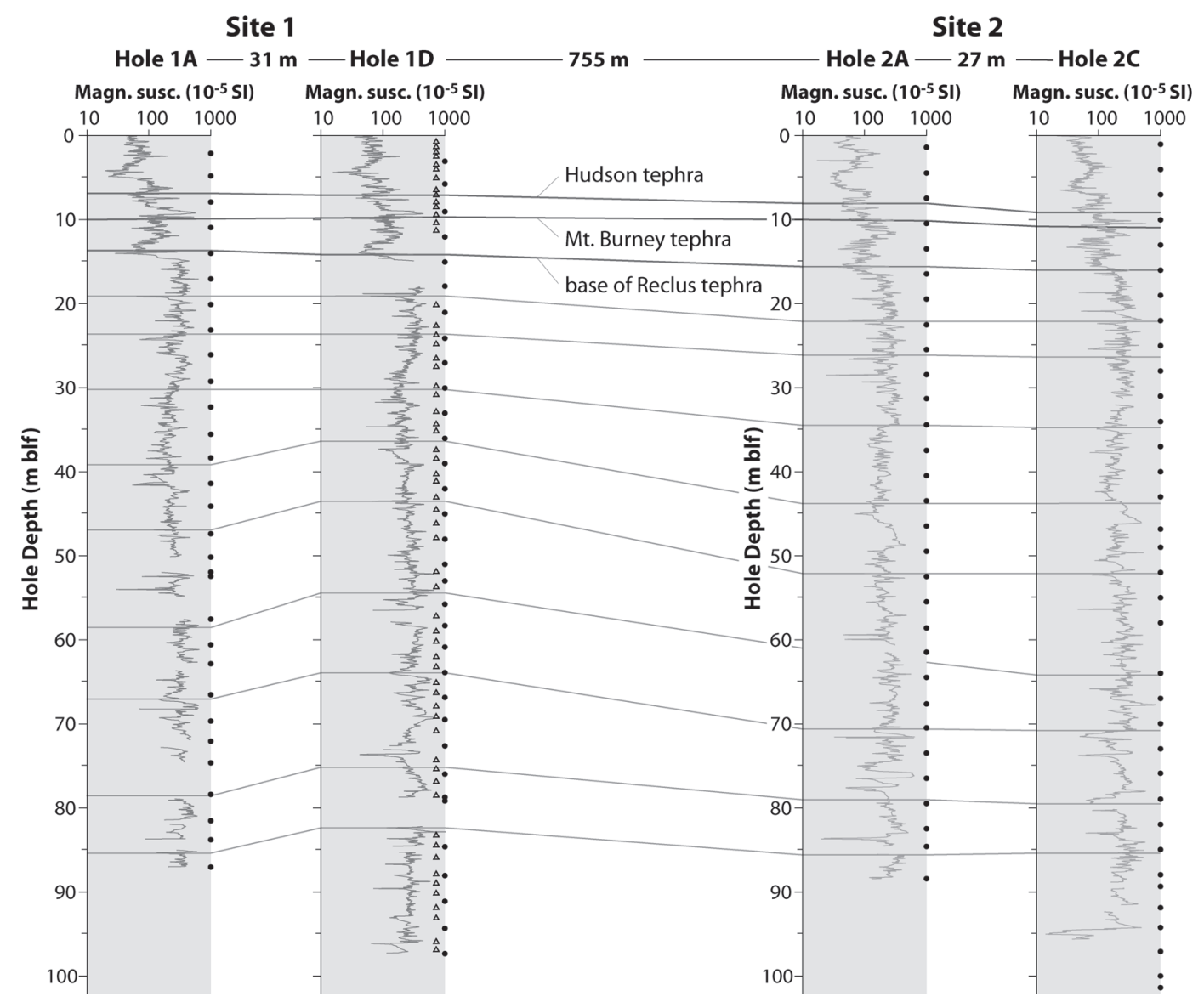

Figure 2. Magnetic susceptibility profiles of cores 5022-IA, -ID, $-2 \mathrm{~A}$ and $-2 \mathrm{C}$ with marker lines allowing correlation of cores within a site and between sites. Three of the correlation lines correspond to the tephra layers mentioned in Table I. Core catcher samples locations are marked with solid circles, and extra samples from hole ID are marked with triangles.

other samples were counted to sums between 7 and 300 pollen grains. Charcoal particles were also counted in the samples, following the method described in Wille et al. (2007).

Diatom assemblages were analyzed in CC samples from hole $1 \mathrm{D}$ and an additional set of 60 samples from the same core was also analyzed. The distribution of these extra samples and their sampling technique is described in detail by Vuillemin et al. (2010). Sample treatment and slide preparation were carried out following standard procedures. Pre-treatment consisted of sample digestion in $30 \%$ hydrogen peroxide of $1 \mathrm{mg}$ of dry sediment. A few drops of $10 \% \mathrm{HCl}$ were added to stop the reaction and remove carbonates. The samples were rinsed several times with deionized water to re-equilibrate the $\mathrm{pH}$ and a few drops of $20 \% \mathrm{NH}_{3}$ were added in the last rinse to ensure the clay removal. Samples were then diluted and a known amount of a solution of microspheres was added to each sample in order to estimate the diatom concentration (Battarbee and Kneen, 1982). The suspension was mounted onto permanent slides for light microscopy following standard procedures (Battarbee, 1986) using Naphrax ${ }^{\circledR}$. A minimum of 400 valves was counted per slide at $\times 100$ magnification under oil immersion in order to calculate relative frequencies. Taxa identification was pursued to species or variety levels using several studies of descriptive general and local diatom floras (Frenguelli, 1923, 1924; Krammer and Lange-Bertalot, 1986, 1988, 1991a, b; Round et al., 1990; Rumrich et al., 2000) and up-to-date publications re-classifying and describing some existing as well as new genera or species (Guerrero and Echenique, 2002; Håkansson and Kling,
1994; Houk and Klee, 2004; Klee et al., 2000; Maidana, 1999; Maidana and Round, 1999).

\section{Results}

\section{Lithology and core correlation}

Composite profiles of both sites, 5022-1CP and 5022-2CP, were achieved by correlation of the corresponding cores, using magnetic susceptibility profiles and supported by visual characteristics on the split cores. This allowed a reliable correlation between cores within the same site and also from site to site (Figure 2). Depths of the core catcher samples were calculated based on the composite profiles (i.e. as meters composite depth $=$ mcd) and interpolated if the samples were outside of the composite profiles.

The combined grain size analyses of the $\mathrm{CC}$ samples from two different cores provide a first picture of associated lithological changes (Figure $3 \mathrm{a}$ and $\mathrm{b}$ ). The retrieved sedimentary record is mainly composed of clays and silts, although sediment grain size varies considerably from fine clays to sands. Furthermore, in some core sections, clearly defined gravel beds are observed. These occur at $76 \mathrm{~m}$ composite depth (mcd) at Site 1 and at $85 \mathrm{mcd}$ and $94 \mathrm{mcd}$ at Site 2. It appears that some of the sand and gravel layers are related to volcanic ash deposition, as they consist of sands with coarser scoria components. Sediment porosity, estimated from calculated mean wet bulk density is shown in Figure 3 for 5022-1CP and 5022-2CP, respectively. Porosity values increase 




Figure 3. Grain size distribution, porosity and bulk organic proxies from the core catcher samples of composite profiles ICP (a) and 2 CP (b).

Table I. Radiocarbon ages of three distinct volcanic ash layers from the literature have been re-calibrated with Calib 5.0.2 (Haberzettl et al., 2007; Stuiver et al., 2005).

\begin{tabular}{lcccr}
\hline Source of tephra layer & Composite depth 5022-2CP $(\mathrm{mcd})$ & Median age $(\mathrm{cal} . \mathrm{BP})$ & Minimum age $(\mathrm{cal} . \mathrm{BP})$ & Maximum age (cal. BP) \\
\hline Hudson & $9.88-10.02$ & $8100^{*}$ & 7670 & 8535 \\
Mt. Burney & $12.32-12.34$ & $8680^{*}$ & 8380 & 8975 \\
Reclus & $16.78-18.24$ & $14,900^{* *}$ & 14,605 & 15,190 \\
\hline
\end{tabular}

Minimum and maximum ages refer to the $2 \sigma$ range. The composite depth for the PASADO record PTA 5022-2CP is given as well as an event-corrected depth for the same record.

*Kilian et al. (2003); **McCulloch et al. (2005).

from around 40 to $50 \%$ in the lower half of the record to about $80 \%$ at 19 mcd. Below 50 mcd no general decreasing trend is visible but single peaks with values up to $80 \%$ occur. In the topmost $19 \mathrm{~m}$ values strongly increase to almost $90 \%$ at the sediment/water interface, except for a single fluctuation to lower values at 13.7 mcd. When compared with deep-sea sediments this trend resembles values comparable with pelagic clays (Hamilton, 1976). However, the strong linear decrease in porosity that occurs between 19 and $50 \mathrm{mcd}$ is not comparable with deep-sea porosity curves. Instead, Laguna Potrok Aike porosities below $50 \mathrm{mcd}$ are at a level that is reached for terrigenous deep-sea sediments in a burial depth of $300 \mathrm{~m}$ or more (Hamilton, 1976).

\section{Chronology}

Ongoing chronological investigations are based on 53 AMS radiocarbon, $31 \mathrm{OSL}$ and $3 \mathrm{Ar} / \mathrm{Ar}$ ages. As the final age/depth relationship is not yet established, we will use a different approach for a preliminary time control of core catcher samples from PTA 5022. The occurrence of three distinct volcanic ash layers from Hudson, Mt Burney and Reclus volcanoes in the topmost $18 \mathrm{~m}$ of the composite record from site 2 (5022-2CP) allows a straightforward stratigraphic correlation to the dated and previously published composite profile PTA03/12+13 (Haberzettl et al., 2007). Corresponding calibrated radiocarbon ages are listed in Table 1 . These 
Background sediment
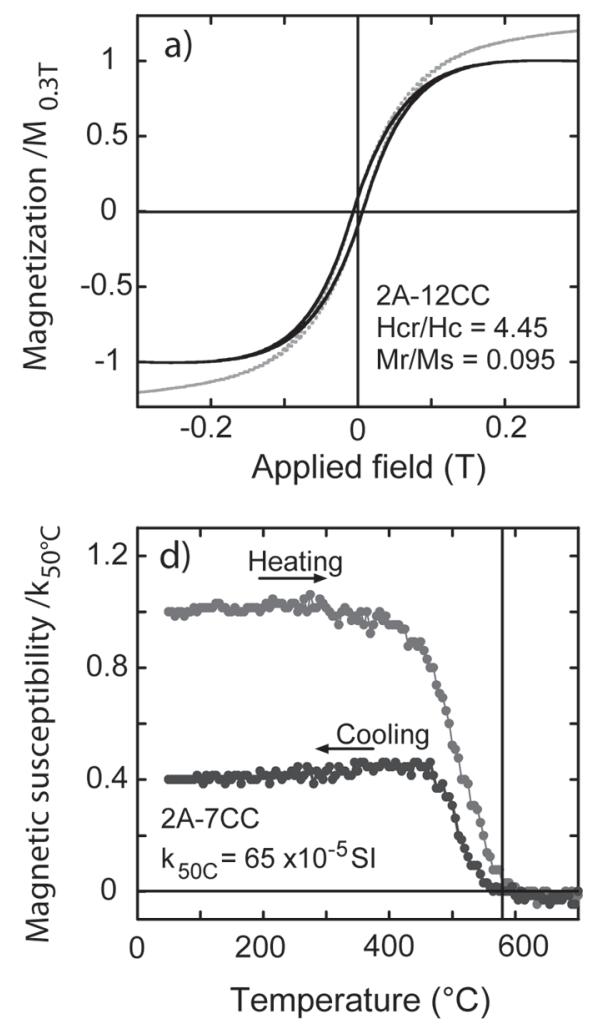

Tephra
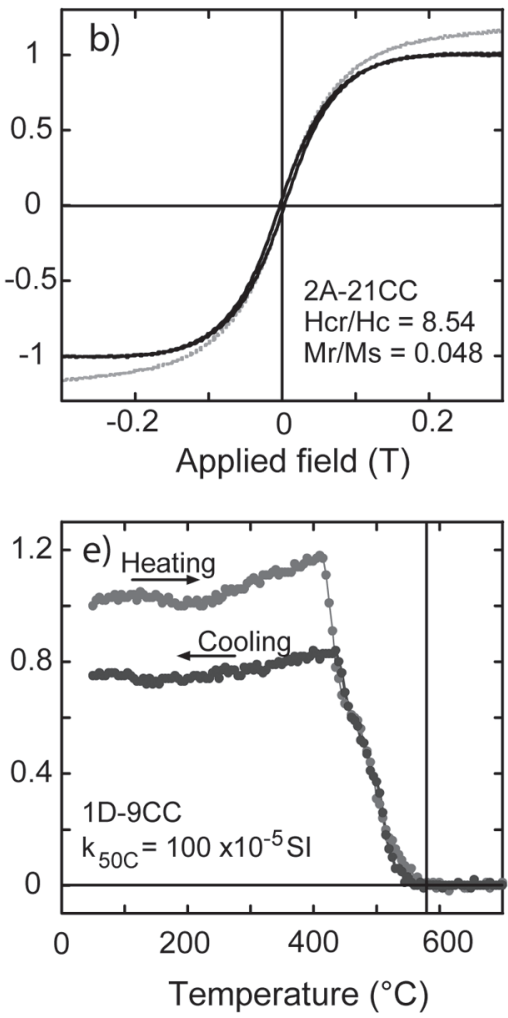

Organic-rich
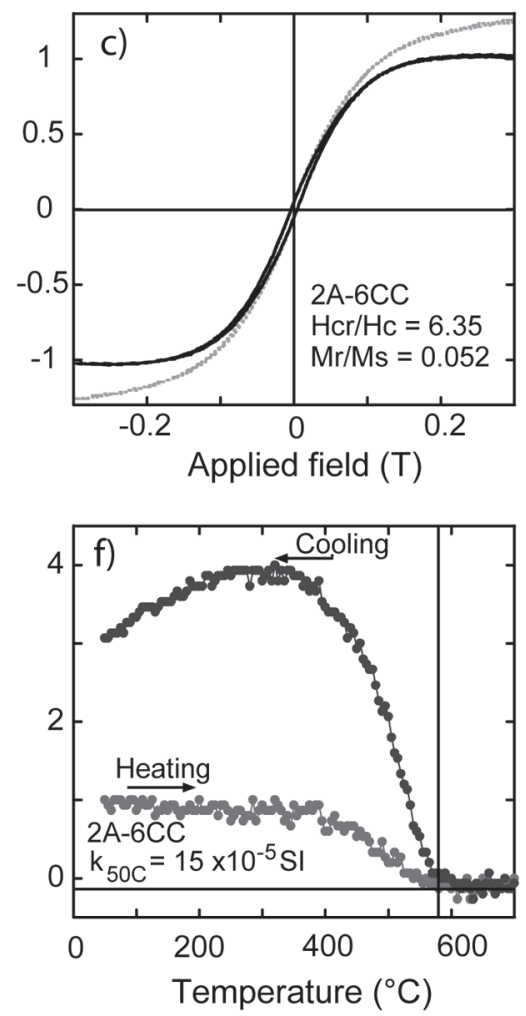

Figure 4. Rock magnetic properties. (a) The typical hysteresis curve for the background sediment presents a narrow loop and the typical shape for magnetite. The hysteresis curves for samples containing (b) tephra material and (c) the organic-rich sample 2A-6CC are narrower and typical of multidomain (MD) and/or superparamagnetic (SP) grains. The grey dashed curve is the raw data and the black curve is the highfield slope corrected data. The magnetization is normalized by the corrected value at the maximum applied field (0.3T). High-temperature dependent magnetic susceptibility heating and cooling curves for (d) a typical background sediment sample, (e) a sample containing tephra material and $(f)$ the organic-rich sample $2 \mathrm{~A}-6 \mathrm{CC}$. The horizontal line indicates zero magnetic susceptibility and the vertical line indicates the theoretical Curie temperature of magnetite $\left(580^{\circ} \mathrm{C}\right.$; Dunlop and Özdemir, 1997). All samples reach zero magnetic susceptibility at or near the Curie temperature of magnetite. The magnetic susceptibility is normalized by the initial value $\left(\right.$ at $\left.50^{\circ} \mathrm{C}\right)$.

tephra layers are used as isochrones to pin down a chronological framework for the last 14.9 cal. ka. To extend this chronology to the base of the record we tentatively use the mean sedimentation rate. However, this value cannot simply be determined and extrapolated for the record from Laguna Potrok Aike as large parts especially of the glacial record, but not only - consist of remobilized sediment sections. Event deposits such as tephra layers and re-deposited sediments related to homogenites, slumps and turbidites indicate a very dynamic depositional environment and contribute to $4.4 \%$ and $47.8 \%$ of sediment thickness, respectively, to the entire record (Kliem et al., 2011). Thus a total of $55.38 \mathrm{~m}$ of rapidly deposited layers have to be excluded from calculations of the sedimentation rate as they are related to instantaneous events. Taking these constraints into account, the sedimentation rate for the Holocene and the Lateglacial sediment record above the Reclus tephra (at 14.7 m event-corrected sediment depth) was calculated using the median age for this volcanic ash layer (Table 1). Thus a mean sedimentation rate of $0.99 \mathrm{~mm} / \mathrm{yr}$ was obtained. Below the Reclus tephra there remain $36 \mathrm{~m}$ of chronologically relevant sediments. Assuming that the linear sedimentation rate calculated for the Holocene and the Lateglacial parts of the record are applicable to the glacial section, a first approximation of its duration is obtained after dividing $36 \mathrm{~m}$ by $0.99 \mathrm{~mm} / \mathrm{yr}$ which yields $36.4 \mathrm{ka}$ of lacustrine deposition. Adding this value to the age of the Reclus tephra (14,900 cal. BP) a preliminary basal age of $51.3 \mathrm{ka}$ is obtained for the PASADO record (5022-2CP). Although all event layers vary considerably between 5022-2CP and 5022-1CP, both records can be correlated (Figure 2) and the tentative age estimation for Site 2 can be transferred to the record from Site 1. The basal age of $51.3 \mathrm{ka}$ estimated in our study is consistent with a first radiocarbon date estimated by Kliem et al. (2011) that reveals a basal age of c. $51 \mathrm{ka}$ cal. BP.

\section{Geochemistry}

Results for the suspension geochemistry, bulk organic geochemistry, porosity and the organic carbon and nitrogen isotope composition of bulk sediment from CC samples from Site 1 and Site 2 are summarized in Figure 3. Samples from each site were merged into composite profiles $1 \mathrm{CP}$ and $2 \mathrm{CP}$ and plotted against depth in med. The trends in the magnetic susceptibility records (Figure 2) show a good correspondence between cores within the same coring site and from Site 1 to Site 2, located more than 750 $\mathrm{m}$ apart, making it possible to correlate records from both sites. $\mathrm{Cl}^{-}$values and conductivity (Figure 3 ) both show only minor fluctuations and a gentle increase from background values around $0 \%$ for $\mathrm{Cl}^{-}$and around $30 \mu \mathrm{S} / \mathrm{cm}$ for conductivity is observed from $50 \mathrm{mcd}$ to $19 \mathrm{mcd}$. Above $19 \mathrm{mcd}$, both proxies show larger fluctuations and a general increasing trend towards the sediment/water interface at both sites. $\mathrm{Ca}^{2+}$ (Figure 3 ) at both sites remains constant 




Figure 5. Day plot for the core catcher samples (CC) from holes ID and 2A. Typical samples for the background sediment (BS), tephra and organic-rich CC samples presented in Figure 4 are circled in black. The data from both sites follow the same trend, with slightly coarser magnetic grains at site ID than at site 2A. The horizontal and vertical lines delimitate the theoretical area for single (SD), pseudo-single (PSD) and multidomain (MD) magnetite grains. The mixing reference curves are from Dunlop (2002).

with values around $0.5 \%$ from the bottom of the record to $19 \mathrm{mcd}$ and then increase to a maximum at the sediment/water interface. At Site 2, a peak with values up to $7.7 \%$ between $7 \mathrm{mcd}$ and 11 mcd is observed, while at Site 1 maximum values stay under $4 \%$. $\mathrm{Ca}^{2+}$ percentages show a good match with TIC determinations done at the off-site lab. TIC values are generally below $0.1 \%$ in the lower part of the record and increase to above $0.2 \%$ in the top $11 \mathrm{mcd}$. The TOC contents are relatively low throughout the record, generally below $1 \%$, slightly increasing towards the top of the record and registering a prominent peak at approximately 16 mod reaching $8 \%$ in both sites. These high values correspond to samples 5022-1A-7CC and 5022-2A-6CC (also characterized by distinct rock magnetic assemblage) respectively, which are organic-rich samples, containing mainly aquatic moss material. This is consistent with an increase in the $\mathrm{C} / \mathrm{N}$-ratio in Site 1 (not visible in Site 2) and less negative $\delta^{13} \mathrm{C}$-values in both records. Moreover, comparatively low $\delta^{15} \mathrm{~N}$ values are observed at the same levels. The $\mathrm{C} / \mathrm{N}$ ratio presents more variability, with values oscillating around 10 and a maximum of 25 at $16 \mathrm{mcd}$ in Site 1 and 19 at 41 mod in Site 2. The variations are reflected by increases of $\delta^{13} \mathrm{C}$ and corresponding decreases in $\delta^{15} \mathrm{~N}$. The carbon isotope composition shows comparably little variation around $-26.0 \%$ in both sites. More enriched values of up to $-22.0 \%$ are reached in the upper $20 \mathrm{~m}$ at Site 2, but not at Site 1. Comparably ${ }^{13} \mathrm{C}$-enriched carbon isotope compositions are reached again around 70 to $90 \mathrm{mcd}$ at Site 2. The nitrogen isotope data of the CC samples from Laguna Potrok Aike show values around 2.5\%o along the main part of the core at Site 2. In both sites investigated, $\delta^{15} \mathrm{~N}$ rises in the upper $15 \mathrm{mcd}$, by up to $3.5 \%$, reaching maximum values of almost $6 \%$ in both sites. The lowermost part of the record shows again higher $\delta^{15} \mathrm{~N}$ values compared to the middle part.

\section{Magnetic mineralogy and grain size}

The assemblage of magnetic grains in 5022-1D and 5022-2A is dominated by low coercivity minerals as indicated by the saturation of the IRM acquisition below $300 \mathrm{mT}$ and the narrow shape of the hysteresis loops (Figure $4 \mathrm{a}-\mathrm{c}$ ). Figure $4 \mathrm{~d}-\mathrm{f}$ presents high-temperature dependent magnetic susceptibility heating and cooling curves of the different types of sediments sampled in the core catchers (background sediments, tephra and organicrich layers). The heating curves of magnetic susceptibility of all the analyzed samples show a sharp decrease at or near the Curie temperature of magnetite, which is $580^{\circ} \mathrm{C}$ (Dunlop and Özdemir, 1997). The magnetic susceptibility measured after cooling represents $47 \pm 8 \%$ of the initial magnetic susceptibility (at $50^{\circ} \mathrm{C}$ ) probably as a result of the oxidation of magnetite to maghemite and hematite during heating (e.g. Henry, 2007; Lepp, 1957) and/or as a result of the single domain (SD) behaviour of superparamagnetic (SP) grains upon cooling (Dearing, 1999). Five samples present an apparently more complex magnetic assemblage. White tephra material, visibly dominant in four samples (5022-1D-9CC, 5022-2A-21CC, -22CC and -27CC) is characterized by higher initial magnetic susceptibility values, sharper decreases of the heating curves to zero magnetic susceptibility and cooling curves partially reversible (Figure 4e). Additionally, sample 5022-2A-6CC has a low initial magnetic susceptibility $\left(15 \times 10^{-5} \mathrm{SI}\right)$ and displays a fourfold increase during cooling (Figure $4 \mathrm{f})$. The coercivity ratio $(\mathrm{Hcr} / \mathrm{Hc})$ and the remanence ratio $(\mathrm{Mr} / \mathrm{Ms})$ are widely used in a biplot known as the Day plot (Day et al., 1977; Dunlop, 2002) to estimate the magnetic grain size and domain state when the magnetic mineralogy is dominated by magnetite. The CC samples of holes $1 \mathrm{D}$ and 2 A cluster along a trend in and to the right of the pseudo single domain (PSD) theoretical area for magnetite (Figure 5). The remanence ratio $(\mathrm{Mr} / \mathrm{Ms})$ is typical of PSD magnetite and the coercivity ratio $(\mathrm{Hcr} / \mathrm{Hc})$ is generally between 3 and 6 . The four samples containing tephra material plot to the lower right end of the cluster of points in the Day plot, suggesting a higher contribution of coarser MD grains and possibly of SP grains (Dunlop, 2002).

\section{Pollen}

Results of the pollen analysis of the core catcher samples from holes $1 \mathrm{D}$ and $2 \mathrm{C}$ are summarized in Figure 6. The two pollen records show considerable differences in quality, the record of hole 1D presenting several gaps because of low pollen content probably associated to coarser sediments. Although the almost continuous record of hole $2 \mathrm{C}$ is better suited for interpretation, major changes can be found in both pollen records. In total, 65 pollen, 11 spores, 5 algal and 15 other non-pollen-palynomorph types were identified. Poaceae dominate both pollen records, with average percentages of $56.9 \%$ in hole $1 \mathrm{D}$ and $55.3 \%$ in hole $2 \mathrm{C}$. Other main contributors to the pollen assemblages are Asteraceae (subf. Asteroideae) $(8.7 \%$ in $1 \mathrm{D}$ and $9.2 \%$ in $2 \mathrm{C}$ ), Caryophyllaceae Arenaria type (5.6\% in 1D and 2C), Caryophyllaceae Colobanthus type (1.3\% in $1 \mathrm{D}$ and $2.3 \%$ and $2 \mathrm{C})$, Cyperaceae $(3.9 \%$ in $1 \mathrm{D}$ and $5.9 \%$ in $2 \mathrm{C}$ ), Nassauvia (4.0\% in 1D and $5.2 \%$ in $2 \mathrm{C}$ ) and Nothofagus dombeyi type (7.9\% in 1D and $6.8 \%$ in $2 \mathrm{C})$. Algae are always present (av. 59.3\% in 1D and 53.4\% in 2C). Below $80 \mathrm{mcd}$ pollen samples are characterized by high values of Colobanthus type (av. $2.7 \%$ in $1 \mathrm{D}$ and $4.1 \%$ in $2 \mathrm{C}$ ). Pollen of Nothofagus dombeyi type is not continuously present in the record but reaches average values of $5.5 \%$ in $1 \mathrm{D}$ and $6.1 \%$ in $2 \mathrm{C}$ if it is present. The concentration of charcoal particles reaches average values of 272 per $\mathrm{ml}$ in $1 \mathrm{D}$ and 307 per $\mathrm{ml}$ in $2 \mathrm{C}$. The middle part of the records ( $80 \mathrm{mcd}$ to $15 \mathrm{mcd}$ in $1 \mathrm{D}$ and $82 \mathrm{mcd}$ to $22 \mathrm{mcd}$ in $2 \mathrm{C}$ ) is 


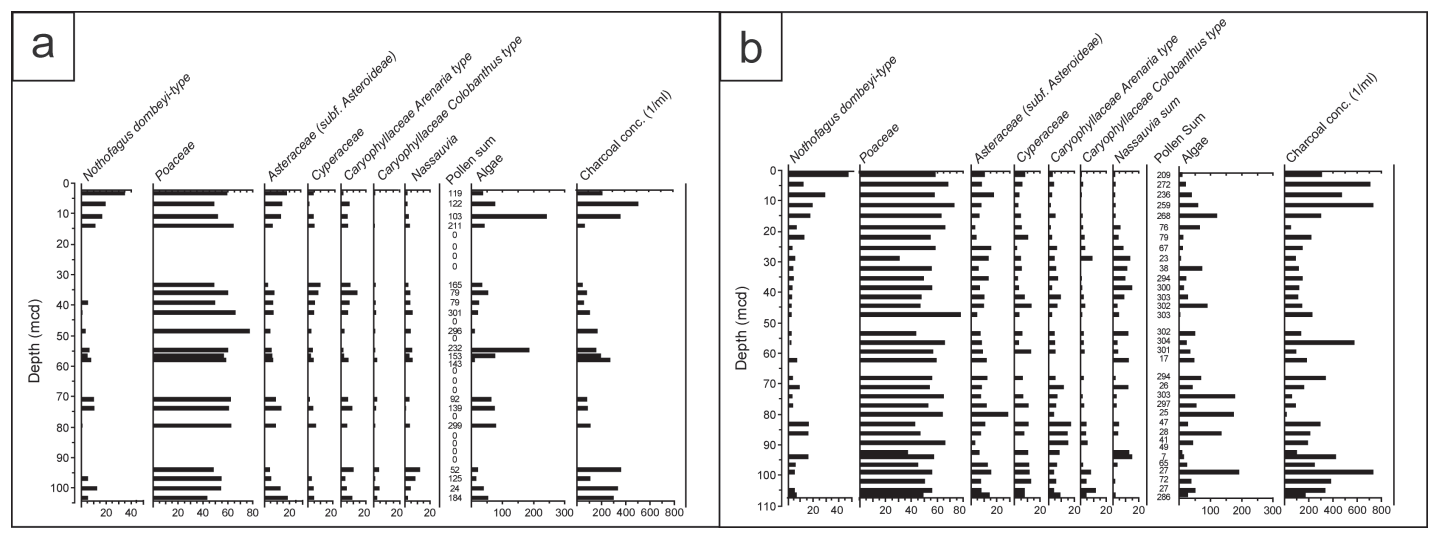

Figure 6. Pollen percentage and pollen concentrations of the most important taxa and charcoal concentration record from the sediment cores 5022-ID (a) and 5022-2C (b). Pollen percentages have been calculated excluding Nothofagus dombeyi. Algae sum is expressed in percentage of the pollen sum.

characterized by relatively low percentages of Nothofagus dombeyi type (av. $4.3 \%$ in $1 \mathrm{D}$ and $2.2 \%$ in $2 \mathrm{C}$ ). Additionally, values of Nassauvia increase to averages of $3.8 \%$ in $1 \mathrm{D}$ and $7.0 \%$ in $2 \mathrm{C}$ and the concentration of charcoal particles decreases to average values of 120 per $\mathrm{ml}$ in $1 \mathrm{D}$ and 158 per $\mathrm{ml}$ in $2 \mathrm{C}$. The uppermost part of both pollen records is characterized by an increase of Nothofagus dombeyi type (av. $4.3 \%$ to $20.2 \%$ in $1 \mathrm{D}$ and $2.2 \%$ to $19.2 \%$ in $2 \mathrm{C}$ ). Other taxa decrease: e.g. Colobanthus type (av. $1.1 \%$ to $0.3 \%$ in $1 \mathrm{D}$ and $1.7 \%$ to $1.0 \%$ in $2 \mathrm{C}$ ) or Nassauvia (av. $3.8 \%$ to $2.4 \%$ in $1 \mathrm{D}$ and $7.0 \%$ to $1.4 \%$ in $2 \mathrm{C}$ ). The concentration of charcoal particles increases to average values of 379 per $\mathrm{ml}$ in $1 \mathrm{D}$ and 500 per $\mathrm{ml}$ in $2 \mathrm{C}$.

\section{Diatoms}

Results of the diatom analysis for hole 1D are summarized in Figure 7. More than 216 species, varieties and forms have been found so far; most of them are cosmopolitan, others known only in America such as Cyclotella agassizensis (Håkansson and Kling, 1994) and Thalassiosira patagonica (Maidana, 1999), some are probably endemics of Patagonia such as Corbellia contorta (Maidana and Round, 1999) or Cyclostephanos patagonicus (Guerrero and Echenique, 2002) and a few new taxa also appear in the record, which will be subject to further studies. The quantitative analysis reveals a diatom abundance ranging from nearly none to 460 million valves per gram of dry sediment, with important fluctuations along the record. Prominent concentration peaks can be spotted at $81 \mathrm{mcd}, 51 \mathrm{mcd}, 33$ to $28 \mathrm{mcd}, 17 \mathrm{mcd}$ and 13 to $10 \mathrm{mcd}$. A CONISS cluster analysis, based on the sum of squares method, was performed and three preliminary zones were distinguished based on the different diatom assemblages. Zone A covers the lower record up to a depth of $23 \mathrm{mcd}$. It is characterized by fluctuations in the ratio of planktonic/nonplanktonic taxa (P/NP) and an increasing relative abundance of fragilarioids towards the top to up to approximately $40 \%$ relative abundance. A peak of the big planktonic diatom Cyclostephanos patagonicus (av. 30\%) occurs at around $69 \mathrm{mcd}$, and this species is not found anymore in the record until more recent times, at 14 to 11 mcd where it became one of the dominant taxa. An isolated peak of Urosolenia sp. occurs at $51 \mathrm{mcd}$ (av. $7 \%$ ) and the species is rare or absent in the rest of the record. Apart from these punctual occurrences of C. patagonicus and Urosolenia sp., plankton in the lowermost $80 \mathrm{~m}$ of the record is dominated by two morphotypes of Discostella stelligera. The typical morphotype is found all along the record but exceptionally large specimens, named here D. stelligera morph 1 (40 to $70 \mu \mathrm{m}$ in diameter) are frequent in the lowermost part of the record (reaching av. 60\%) and decrease gradually until $63 \mathrm{mcd}$. Above that depth, they are rarely found and only the typical morphotype persists, oscillating between $20 \%$ and $70 \%$ along this zone. Zone B (23 mcd to $13 \mathrm{mcd})$ is characterized by an important increase of non-planktonic species, especially the fragilarioid taxa. Indeed, the P/NP ratio is close to zero in this zone. The dominant fragilarioid taxa reach concentrations above $60 \%$ and only D. stelligera represents the plankton fraction. Zone C (13 mcd to the top) is dominated by Cyclostephanos patagonicus between 14 to $11 \mathrm{mcd}$, with values of up to $66 \%$, and this species gets replaced by Cyclotella agassizensis (increasing from $20 \%$ to $70 \%$ in the topmost $2 \mathrm{~m}$ ) and Thalassiosira patagonica (with values up to $15 \%$ in the lower part of this zone) towards the top of the record. These indicators of more brackish conditions appear for the first time in this zone and are generally missing in older sediments. Discostella stelligera continues to be present in this zone, with approximate values of 20 to $40 \%$ and non-planktonic taxa such as Cocconeis placentula vars. and fragilarioids species both occur with values from approximately $5 \%$ to $30 \%$.

\section{Discussion and interpretation}

\section{Sedimentology}

Rock magnetic analyses suggest that a low coercivity mineral such as magnetite (Figure 4) is the dominant magnetic carrier of remanence in the sediments for the last $51.3 \mathrm{cal}$. ka BP. The estimated magnetic grain size using the hysteresis parameters (Figure 5) indicates a dominance of PSD grains, with all data points following the reference line for single- and multidomain (SD+MD) grains. The shift to the right could indicate a contribution of superparamagnetic (SP) grains (Dunlop, 2002) or a minor contribution of magnetic minerals other than magnetite. The latter is more likely as previous analysis of frequency-dependent magnetic susceptibility performed on short sediment cores from Laguna Potrok Aike reveals that the contribution of SP grains at roomtemperature is small $(<4 \%)$ in the uppermost $c .1 \mathrm{~m}$ in the central basin (Gogorza et al., 2011; Haberzettl et al., 2005). Nonetheless, the trends in the Day plot for 1D and 2A samples (Figure 5) indicate a common source of magnetic grains with a position along the trend most likely controlled by grain size variations (Dunlop, 2002; Dunlop and Özdemir, 1997). The hysteresis parameters of samples from hole 1D generally display higher $\mathrm{Hcr} / \mathrm{Hc}$ and lower $\mathrm{Mr} / \mathrm{Ms}$ ratios than the samples from hole 2A, indicating the presence of slightly coarser magnetic grains (Figure 5). Likewise, bulk sediment grain size analyses (Figure 3) show overall coarser material at Site 1 than at Site 2. Moreover, the 





cores obtained at Site 1 have a lower recovery rate and apparently contain more redeposited material than at Site 2. The differences between cores from both sites in the central basin are consistent with the modern processes controlling sediment deposition in Laguna Potrok Aike (Kastner et al., 2010), with Site 1 located closer to the area where downward slope transport, induced by the strong westerly winds, and lake level changes occur. Moreover, Site 1 is located much closer to the present ephemeral inlet of the lake. In addition, the five core catcher samples dominated by tephra (5022-1D-9CC, 5022-2A-21CC, -22CC and -27CC) and organic material (5022-2A-6CC) were easily identified from their magnetic properties (Figures 4 and 5), thus highlighting the potential of rock magnetic properties to trace reworked sedimentary layers in further high-resolution investigations.

Bulk organic geochemistry and isotopic composition shed light on the plant origin and provenance of sedimentary organic matter in Laguna Potrok Aike. Investigation of modern surface sediments from Laguna Potrok Aike shows a homogenous distribution of TOC in the deep basin reflecting mixing of organic material within the lake and preferred accumulation in the deeper areas compared to the shore line (Kastner et al., 2010). These authors obtained similar results for the organic carbon isotopic composition throughout the basin. $\mathrm{C} / \mathrm{N}$ ratios are commonly used to determine whether the organic matter in lacustrine sediments has an algal or a terrestrial origin (e.g. Meyers and Teranes, 2001). Organic matter of terrestrial origin (derived from vascular plants) typically has $\mathrm{C} / \mathrm{N}$ ratios $>20$ and organic matter of aquatic origin (derived from algae) typically presents $\mathrm{C} / \mathrm{N}$ values $<10$. Lacustrine organic matter is generally a mixture of terrestrial and aquatic organic matter, thus $\mathrm{C} / \mathrm{N}$ ratios are used to identify the relative contributions of these two sources to the sediment. Figure 3 shows that $\mathrm{C} / \mathrm{N}$ ratios are below or around 10 throughout the record, indicating a predominantly algal source for the sedimentary organic matter practically for the whole record. An exception occurs between 18 and $10 \mathrm{mcd}$ at Site 1 , with values increasing above 20 . This increase includes a peak of TOC and at the same depth at Site 2 the core catcher sample 5022-2A-6CC is characterized by an increased magnetic susceptibility upon cooling from $600^{\circ} \mathrm{C}$ (Figure 4f). Such magnetic properties are common of para- and antiferro-magnetic material (Dearing, 1999) and the presence of organic matter can contribute to such a formation of iron oxides (Henry, 2007). Altogether the $\mathrm{C} / \mathrm{N}$ ratio, TOC and magnetic properties suggest an input of vascular plant organic matter at this depth.

The concentration of diatoms strongly fluctuates along the record. Important concentration peaks can be spotted along the record, most probably corresponding to diatom blooms. These could reflect variations in the nutrient availability in the system, either because of a higher external input, by remobilization (turbidites, slumps, stronger currents) or triggered by favorable climatic conditions for the living flora. Nevertheless, a more detailed analysis of the data is necessary to further develop these hypotheses. The diatom concentration peak at $81 \mathrm{mcd}$ shown in the diatom diagram (Figure 7) can be tracked to Site 2 to a depth of 83 mcd which corresponds to a laminated sequence overlaying a major mass-wasting event. Thus, it is likely that this bloom has been triggered by changes in nutrient availability due to the re-suspension of material by this major mass-wasting event. The smaller peak at around $51 \mathrm{mcd}$ corresponds to another rapidly deposited layer, located at $c .56 \mathrm{~m}$ in Site 2. At $27 \mathrm{mcd}$ in Site 1, a tephra layer occurs (sample 50221D-9CC supported by its rock-magnetic signature), corresponding to an increase in diatom concentration (Figure 7). Tephras can also affect the nutrient balance in a lake system and thus drive climatically independent variations in diatom concentration. These peaks occur for the whole floral assemblage, and suggest massive events that re-suspend material all over the lake, likely originating from the lake center as well as from the shore areas were benthic taxa dominate.
Today, Laguna Potrok Aike is a subsaline lake with high $\mathrm{Cl}^{-}$ concentrations of approximately $500 \mathrm{mg} / \mathrm{l}$ in the water column (Zolitschka et al., 2006). The $\mathrm{Cl}^{-}$profile most likely mirrors the contribution of $\mathrm{Cl}$-bearing pore water to the sediment suspension and the same is true for the conductivity data. The fact that the $\mathrm{Cl}^{-}$ and conductivity profiles closely resemble the shape of the porosity curve indicates that no easily soluble minerals are present in the entire sediment sequence. The porosity curve determined by first field estimates of mean wet bulk densities indicates that, compared with a normally compacting deep-sea sediment (Hamilton, 1976), sediments below 19 mcd from Laguna Potrok Aike are overcompacted, i.e. the overburden pressure was higher than it would be expected from the burial depth. Such a feature, according to Faas (1982), may result from several processes e.g. (i) removal of sedimentary overburden, through erosion or faulting, (ii) desiccation, (iii) cementation and recrystallization in the sediment, or (iv) lateral compression. All of these possible reasons would have important implications for the interpretation of the sedimentary record because this would mean that the sediments below 19 mcd are either heavily disturbed because of the effects of slumping and/or diagenetic processes, or drastic erosion events occurred that gave rise to hiatuses of yet unknown duration. The abrupt drop in porosities at 13.7 mod most likely can be ascribed to a package of slumped sediments that have higher compaction rates than the sediments above and below. In contrast, the peaks of increased porosities below 50 mcd mostly are associated to layers of sand, gravel or redeposited tephra that prevented a complete filling of the liner with sediment during the coring process and thus are coring artifacts. However, these hypotheses are just based on first field measurements with a very coarse spacial resolution and need to be verified by more detailed analyses of the entire record. Therefore a high resolution and more precise estimation of sediment densities, porosities and compaction rates is currently under way by the analysis of sediment core logging data acquired with a Multi Sensor Core Logger at $2 \mathrm{~cm}$ resolution for the entire composite profile (Gebhardt, unpublished data, 2009). Yet, another possible explanation for the overcompaction would be the presence of an overlying ice sheet during the last glaciation. Although the literature suggests that glaciations in the Late Pleistocene did not extend far enough east to reach the Pali Aike Volcanic Field (Zolitschka et al., 2006), the reconstructed ice limit for the Late Pleistocene ice sheet expansion is sensitively close to the study area (Rabassa, 2008). Although it is not likely that an ice sheet covered Laguna Potrok Aike at that time, more detailed geomorphological studies in the area would help to completely rule out this hypothesis.

\section{Paleoenvironmental implications since the Late Pleistocene}

Previous investigations of lacustrine sediments of eastern and southern Patagonia provide some information on the Lateglacial to Holocene climate evolution in the area. The new PASADO sediment cores reach as far back as the Late Pleistocene, thus covering glacial times and yielding new information about environmental and hydrological conditions during this time period. The $\mathrm{Ca}^{2+}$ profile shows that easily acid soluble carbonates are present in the topmost $19 \mathrm{~m}$ of the sediment record as already reported by Haberzettl et al. (2007) but not below this depth. Similar observations were made in a piston core from a lake level terrace showing very low resolution and hence giving information about littoral sedimentation for an even longer period (Haberzettl et al., 2008, 2009). This documents the fundamental difference between mostly endorheic Holocene and Lateglacial conditions on one hand and glacial conditions characterized by a different hydrology on the other hand. A possible explanation for this could be that Laguna Potrok Aike was a hydrologically open system during 
glacial times. This would imply that the lake was most of the time filled with water up to a level where overflow occurs, at $21 \mathrm{~m}$ above the present-day lake level as is proposed by Haberzettl et al. (2009). Although there is morphological evidence for the existence of such an overflow at the NW shore of the lake, this may not be the only process that prevents the precipitation of carbonates. Deeply buried sand dunes and paleo-shorelines are observed in the seismic data (Gebhardt et al., 2011), and show that the lake not always experienced lake-level highstands, but also times of low lake level and even desiccation. These horizons, however, were not penetrated with the long core and thus do not show up in our core catcher record.

The elemental concentrations and stable isotope data from the top $20 \mathrm{~m}$ presented on this study relate very well to the reconstructed organic matter dynamics of Laguna Potrok Aike and the climatically induced hydrological variations (with related lake level fluctuations) based on the previous analyses of a $19 \mathrm{~m}$ piston core (Haberzettl et al., 2007; Mayr et al., 2009). These previous results clearly show all Holocene and Lateglacial paleoclimate characteristics known for this region. Detailed analyses of modern aquatic and terrestrial organic matter as presented in Mayr et al. (2009) and Kastner et al. (2010) revealed that $\delta^{13} C_{\text {org }}$ values represent mainly a mixture of diatoms and cyanobacteria with varying admixtures of soil organic matter and aquatic macrophytes. In the lower part of the cores $(>20 \mathrm{mcd})$ the organic carbon content is lower than in the upper part and the $\mathrm{C} / \mathrm{N}$, $\delta^{13} \mathrm{C}_{\text {org }}$ and $\delta^{15} \mathrm{~N}$ data show comparably little variation. Accordingly, the glacial conditions are represented by generally decreased lacustrine productivity and increased clastic input compared with younger periods. It can be assumed that the relative input of allochthonous organic matter, e.g. from soils and rock weathering, has increased accordingly. This interpretation, however, needs to be backed-up by more detailed analyses of the composite cores. Between approximately 74 and $85 \mathrm{mcd}$ at Site 2, increased $\delta^{13} \mathrm{C}_{\text {org }}$ values indicate different environmental conditions. This phase might be interpreted as a period of higher lacustrine productivity caused by improved nutrient availability and/or improved climatic conditions. Higher resolution analyses including a detailed study of discrete plant debris layers will further evaluate this hypothesis.

Previous studies carried out at Laguna Potrok Aike by Haberzettl et al. (2007) determined the sediment sequence as predominantly minerogenic. Holocene and Lateglacial sediments, however, are distinguished from full glacial sediments by considerably higher TOC and TIC contents. The increased TOC indicates enhanced lacustrine primary productivity during the warmer Holocene climate. Smear slide analyses demonstrate that the increase in calcium and TIC results from autochthonous calcite precipitation. Thus, TIC and calcium content point to lower lake levels during the warmer and probably drier Holocene conditions, which drove calcite precipitation as a result of supersaturation in the water column (Haberzettl et al., 2007). The depth of 10 to $15 \mathrm{mcd}$ is the transition period between warmer postglacial and colder glacial climate conditions and is marked by the increased presence of plant macroremains and stems of aquatic mosses, which present the highest TOC values of the record. The high $\mathrm{C} / \mathrm{N}$ ratios seen in Site 1 indicate a change in the source of organic matter during the Lateglacial.

The vegetation remains in the records also witness of climatic changes since the Late Pleistocene. Both pollen records indicate that the study area was covered with Patagonian Steppe vegetation during the last $51.3 \mathrm{cal}$. ka BP. However, the steppe vegetation underwent some changes through time, which are manifested in fluctuations of the pollen assemblages. The oldest part of both pollen records, corresponding to glacial times, shows a relatively high contribution of Colobanthus type, which is nowadays mainly distributed in the dry steppe of Patagonia. As it must be considered that the comparatively heavy pollen grains of Caryophyllaceae are not transported for long distances, the origin of this signal must be regarded as coming from the immediate catchment area of Laguna Potrok Aike. In contrast, the presence of Nothofagus pollen is due to its presence in the Andes in a minimum distance of $60 \mathrm{~km}$ to the west. Fire activity seemed to be comparable with Holocene times as the concentrations of charcoal particles in the uppermost and lowermost parts of the record are similar. We interpret this pollen signal as glacial, because compared with modern conditions, the vegetation around Laguna Potrok Aike during glacial times had a higher contribution of dwarf shrubs, indicating conditions drier than today. However in the Andean area Nothofagus was present probably as shrubs as it occurs today close to its lower temperature limits. Around $80 \mathrm{mcd}$ conditions changed as Nothofagus and charcoal concentrations decreased and Nassauvia increased importantly. Nowadays Nassauvia is abundant in the driest parts of the Patagonian Steppe but also as an element of high altitude vegetation in the southern Andes where growing conditions are limited by low temperatures. Based on this pollen signal we suggest glacial conditions with considerably lower temperatures and probably lower humidity than before. The uppermost parts of the pollen records confirm an already well-known and well-dated spread of Nothofagus forest in the Andes (Wille et al., 2007) while elements of the driest steppe such as Colobanthus and Nassauvia decrease. We interpret this pollen signal as a warming with a contemporaneous increase in humidity during the Lateglacial and earliest Holocene times.

The diatom record shows a clear change in trends between the lowermost part of the record (below $23 \mathrm{mcd}$ ) and the uppermost part. Changes in the dominant floral assemblages occur at the transition from glacial to Holocene times. The lower $80 \mathrm{~m}$ of the profile, corresponding to glacial times require higher resolution analyses to allow defining past environmental conditions. The peaks of Urosolenia sp. at $51 \mathrm{mcd}$ and C. patagonicus at $69 \mathrm{mcd}$ introduce some new information about hydrological changes in the lake. The presence of Urosolenia sp. is generally an indicator of freshwater input in the system, although a better constrained age model and higher resolution analyses are necessary to better define this supposition. The occurrence of $C$. patagonicus at approximately $69 \mathrm{mcd}$ points to a freshwater lake and could indicate a rise of the lake level. This could be pointing at lower lake levels below this depth. Small planktonic and benthic taxa could have survived at low water levels although the large D. stelligera morph 1 of would have needed a more significant water column, with high turbulence to maintain it in suspension and/or colder and thus denser waters. This taxon is abundant in the lowermost part of the record and declines to very low values above $65 \mathrm{mcd}$. Since diatoms are sensitive to a very wide range of environmental variables, this at first sight inconsistent evidence will likely be clarified by higher resolution analyses and will help unravel the hydrological history of Laguna Potrok Aike. We can exclude the possibility of the 69 mcd peak of C. patagonicus being associated to contamination of the CC sample by present day's water during drilling operations since (i) some of the samples bearing the $C$. patagonicus come from freshly cut windows in the core (Vuillemin et al., 2010), (ii) if it were the case, there would also be contamination with the modern dominant flora, but no C. agassizensis valves are found in those samples, and (iii) likewise, the suspension geochemistry data set does not show any increase of $\mathrm{Ca}^{2+}, \mathrm{Cl}^{-}$or organic matter at this level. The relative increase of non-planktonic taxa between 13 and $23 \mathrm{mcd}$, dominated by fragilarioid taxa, could be related to lake-level changes and/or periods of ice-cover development. At about $13 \mathrm{mcd}$, the increase and high proportion of the freshwater diatom $C$. patagonicus indicates that the water must have been clear and fresh in Lateglacial times. Its steady decrease coupled to the contemporaneous increase of T. patagonica might be due to increasing salinity in the lake, as this diatom is indicator of 
saline waters. Synchronously, C. agassizensis, which is associated with lower lake levels, became abundant, suggesting that the Holocene climate in the area was warmer and drier. The results of the top c. $17 \mathrm{~m}$ of this analysis are consistent with previous results published by Wille et al. (2007), on a $19 \mathrm{~m}$ core from the former SALSA project. Moreover, the appearance of $C$. patagonicus in this previous record at approximately $15.5 \mathrm{cal}$. ka BP allows us to tentatively pinpoint this age in the new cores (because of the $3 \mathrm{~m}$ sampling resolution that age estimate is somewhere between 14 and $17 \mathrm{mcd}$ ). Another age control we could infer from that shorter core is the 8.6 cal. ka BP corresponding to the peak in T. patagonica, which in our record occurs between $10 \mathrm{mcd}$ and $12 \mathrm{mcd}$.

\section{Conclusions}

This contribution presents the first multiproxy record from the PASADO sedimentary cores of Laguna Potrok Aike and aims to highlight the potential of studying core-catcher samples. Indeed, low resolution analyses allow for a quick preliminary assessment of climatic and environmental changes throughout the whole record and help locating the areas of interest where higher resolution studies shall be focused. Combining preliminary information from sedimentology, rock magnetism, geochemistry, elemental analysis, stable isotopes, pollen and diatom analyses allowed characterizing compositional variations in the sediment throughout the core (tephra layers, mass wasting events), getting a first idea on climatic evolution for the last 51.3 cal. ka BP and identifying variations in the hydrological balance of the lake. Furthermore, preliminary microfossil and geochemical results reveal a clear difference between Holocene and glacial conditions, supported by changes in the bulk geochemical parameters and shifts in the diatom and pollen assemblages. If glacial sediments reflect colder and drier conditions, the Lateglacial to Holocene record is characterized by a warming climate and increase in humidity, as reflected by the increase of primary production in the lake and the decrease of the driest steppe elements in the pollen record. Finally, the ongoing Argentinian project PIPA (Proyecto Interdisciplinario Patagonia Austral, PICT/R 02338), an interdisciplinary approach combining geological, biological and archaeological investigations, aims at producing for the first time modern training sets in Patagonia, as part of the efforts to increase the available information on the different environments of this remote area of the world. The multiproxy approach of the PASADO project combined with the modern training set for Patagonia will provide unique paleoecological information for the Southern Hemisphere and help characterize Late Pleistocene to modern times.

\section{Acknowledgements}

For their invaluable help in field logistics and drilling we would like to thank the staff of INTA Santa Cruz and Rio Dulce Catering as well as the Moreteau family and the DOSECC crew. Pauline Masset is thanked for her assistance with grain size analysis. For their valuable comments and revisions of earlier versions of the manuscript, Dr Stéphanie Girardclos and Dr Daniel Veres are kindly acknowledged. We also thank Dr Sonia Fontana, Dr Marcella Tonello and an anonymous reviewer for their constructive remarks that have helped improve the manuscript.

\section{Funding}

This research is supported by the International Continental Scientific Drilling Program (ICDP) in the framework of the 'Potrok Aike Maar Lake Sediment Archive Drilling Project' (PASADO). Funding for drilling was provided by the ICDP, the German Science Foundation (DFG), the Swiss National Funds (SNF), the Natural
Sciences and Engineering Research Council of Canada (NSERC), the Swedish Vetenskapsradet (VR) and the University of Bremen.

\section{References}

Anselmetti FS, Ariztegui D, De Batist M et al. (2009) Environmental history of southern Patagonia unravelled by the seismic stratigraphy of Laguna Potrok Aike. Sedimentology 56: 873-892.

Ariztegui D, Anselmetti FS, Gilli A et al. (2008) Late Pleistocene environmental change in eastern Patagonia and Tierra del Fuego - A limnnogeological approach. In: Rabassa J (ed.) The Late Cenozoic of Patagonia and Tierra del Fuego. Elsevier, 241-253.

Battarbee RW (1986) Diatom analysis. In: Berglund BE (ed.) Handbook of Holocene Palaeoecology and Palaeohydrology. New York: J. Wiley, pp. 527-570.

Battarbee RW and Kneen MJ (1982) The use of electronically counted microspheres in absolute diatom analysis. Limnology and Oceanography 27: 184-188.

Day R, Fuller M and Schmidt VA (1977) Hysteresis properties of titanomagnetites grain-size and compositional dependence. Physics of the Earth and Planetary Interiors 13: 260-267.

Dearing J (1999) Environmental Magnetic Susceptibility - Using the Bartington MS2 System. Second edition. Kenilworth: Chi Publishing.

Dunlop DJ (2002) Theory and application of the Day plot (M-rs/M-s versus $\mathrm{H}-\mathrm{cr} / \mathrm{H}-\mathrm{c}) 1$. Theoretical curves and tests using titanomagnetite data. Journal of Geophysical Research-Solid Earth 107(B3): 2056, 22 pp.

Dunlop DJ and Özdemir Ö (1997) Rock Magnetism: Fundamentals and Frontiers. Cambridge University Press.

Faas RW (1982) 30. Gravitational compaction patterns determined from sediment cores recovered during the Deep Sea Drilling Project Leg 67 Guatemalan transect: Continental slope, middle America trench, and Cocos Plate. Initial Reports DSDP 67: 617-638.

Fey M, Korr C, Maidana NI et al. (2009) Palaeoenvironmental changes during the last 1600 years inferred from the sediment record of a cirque lake in southern Patagonia (Laguna Las Vizcachas, Argentina). Palaeogeography Palaeoclimatology Palaeoecology 281: 363-375.

Frenguelli J (1923) Resultados de la Primera Expedición a Tierra del Fuego (1921) - Diatomeas de Tierra del Fuego. Anales de la Sociedad Cientifica Argentina 96: 225-263.

Frenguelli J (1924) Resultados de la Primera Expedición a Tierra del Fuego (1921) - Diatomeas de Tierra del Fuego. Anales de la Sociedad Científica Argentina 97: 87-118, 231-266; 98: 5-63.

Gebhardt AC, Ohlendorf C, Niessen F et al. (2011) Seismic evidence of up to $200 \mathrm{~m}$ lake-level change in Southern Patagonia since Marine Isotope Stage 4. Sedimentology doi: 10.1111/j.1365-3091.2011.01296.x.

Gilli A, Anselmetti FS, Ariztegui D et al. (2001) Tracking abrupt climate change in the Southern Hemisphere: A seismic stratigraphic study of Lago Cardiel, Argentina (49 $\mathrm{S})$. Terra Nova 13: 443-448.

Gogorza CSG, Sinito AM, Ohlendorf C et al. (2011) Paleosecular variation and paleointensity records for the last millennium from southern South America (Laguna Potrok Aike, Santa Cruz, Argentina). Physics of the Earth and Planetary Interiors 184: 41-50.

Guerrero JM and Echenique RO (2002) Cyclostephanos patagonicus sp. nov., a new freshwater diatom from Western Patagonia (Argentina) Diatom Research 17: 141-151.

Haberzettl T, Anselmetti FS, Bowen SW et al. (2009) Late Pleistocene dust deposition in the Patagonian steppe - extending and refining the paleoenvironmental and tephrochronological record from Laguna Potrok Aike back to 55 ka. Quaternary Science Reviews 28: 2927-2939.

Haberzettl T, Corbella H, Fey M et al. (2007) Late glacial and Holocene wetdry cycles in southern Patagonia: Chronology, sedimentology and geochemistry of a lacustrine record from Laguna Potrok Aike, Argentina. The Holocene 17: 297-310.

Haberzettl T, Fey M, Lücke A et al. (2005) Climatically induced lake level changes during the last two millennia as reflected in sediments of Laguna Potrok Aike, southern Patagonia (Santa Cruz, Argentina). Journal of Paleolimnology 33: 283-302.

Haberzettl T, Kuck B, Wulf S et al. (2008) Hydrological variability in southeastern Patagonia and explosive volcanic activity in the southern Andean Cordillera during Oxygen Isotope Stage 3 and the Holocene inferred from lake sediments of Laguna Potrok Aike, Argentina. Palaeogeography Palaeoclimatology Palaeoecology 259: 213-229.

Haberzettl T, Wille M, Fey M et al. (2006) Environmental change and fire history of southern Patagonia (Argentina) during the last five centuries. Quaternary International 158: 72-82. 
Håkansson H and Kling H (1994) Cyclotella agassizensis nov. sp. and its relationship to C. quillensis Bailey and other Prairie Cyclotella species. Diatom Research 9: 289-301.

Hamilton EL (1976) Variations of density and porosity with depth in deep-sea sediments. Journal of Sedimentary Petrology 46: 280-300.

Henry B (2007) Magnetic mineralogy, changes due to heating. In: Gubbins D and Herrero-Bervera E (eds) Encyclopedia of Geomagnetism and Paleomagnetism. Springer-Verlag, pp. 512-515.

Houk V and Klee R (2004) The stelligeroid taxa of the genus Cyclotella (Kützing) Brebisson (Bacillariophyceae) and their transfer into the new genus Discostella gen. nov. Diatom Research 19: 203-228.

Kastner S, Ohlendorf C, Haberzettl T et al. (2010) Southern hemispheric westerlies control the spatial distribution of modern sediments in Laguna Potrok Aike, Argentina. Journal of Paleolimnology 44: 887-902.

Kilian R, Hohner M, Biester H et al. (2003) Holocene peat and lake sediment

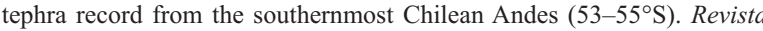
Geologica de Chile 30: 23-37.

Klee R, Houk V and Bielsa S (2000) Cyclotella mascarenica nov. spec., a new stelligeroid Cyclotella (Bacyllariophyceae) from a pond of the Réunion Island (France). Archiv für Hydrobiologie (Alg. Studies 98, 133: 7-25.

Kliem P, Buylaert JP, Hahn A et al. (2011) Dating, age-depth modeling and hydrological interpretation of the 51 cal. ka BP composite profile from Laguna Potrok Aike in Southern Patagonia, Argentina. In: 3rd Interna tional PASADO Workshop. Montreal, Canada, 21-23 March, pp. 31-32. Available at http://www.pasado.uni-bremen.de/Files/3rd Pasado_WS _Mtl_2011.pdf

Kliem P, Hahn A, Ohlendorf C et al. (2010) Characterization of mass movement deposits in the south Patagonian maar lake Laguna Potrok Aike, Argentina. Terra Nostra 2010(1): 36-39.

Krammer K and Lange-Bertalot H (1986) Bacillariophyceae 1. Teil: Naviculaceae. In: Ettl H, Gerloff J, Heynig H et al. (eds) Süßwasserflora von Mitteleuropa 2/1. Jena: G. Fischer.

Krammer K and Lange-Bertalot H (1988) Bacillariophyceae 2. Teil: Bacillariaceae, Epithemiaceae, Surirellaceae. In: Ettl H, Gerloff J, Heynig H et al. (eds) Süßwasserflora von Mitteleuropa 2/2. Jena: G. Fischer.

Krammer K and Lange-Bertalot H (1991a) Bacillariophyceae 3. Teil: Centrales, Fragilariaceae, Eunotiaceae. Unter Mitarbeit von H. Håkansson und M. Nörpel. In: Ettl H, Gerloff J, Heynig H et al. (eds) Süßwasserflora von Mitteleuropa 2/3. Jena, Stuttgart: G. Fischer.

Krammer K and Lange-Bertalot H (1991b) Bacilliariophyceae 4. Teil: Achnanthaceae, Kritische Ergänzungen zu Navicula (Lineolatae) und Gomphonema. In: Ettl H, Gärtner G, Gerloff J et al. (eds) Süßwasserflora von Mitteleuropa 2/4. Stuttgart: G. Fischer.

Lepp H (1957) Stages in the oxidation of magnetite. The American Mineralogist42: 679-681.

Maidana NI (1999) Thalassiosira patagonica sp. nov. (Thalassiosiraceae, Bacillariophycaea), a new lacustrine centric diatom from Santa Cruz, Argentina. Diatom Research14: 323-329.

Maidana NI and Round FE (1999) Corbellia contorta gen. \& sp. nov. (Bacillariophyceae). A new diatom genus from Santa Cruz Province (Argentina) Diatom Research 14: 331-336.

Markgraf V, Bradbury JP, Schwalb A et al. (2003) Holocene palaeoclimates of southern Patagonia: Limnological and environmental history of Lago Cardiel, Argentina. The Holocene 13: 581-591.

Mayr C, Fey M, Haberzettl T et al. (2005) Palaeoenvironmental changes in southern Patagonia during the last millennium recorded in lake sediments from Laguna Azul (Argentina). Palaeogeography Palaeoclimatology Palaeoecology 228: 203-227.
Mayr C, Lücke A, Maidana NI et al. (2009) Isotopic fingerprints on lacustrine organic matter from Laguna Potrok Aike (southern Patagonia, Argentina) reflect environmental changes during the last 16,000 years. Journal of Paleolimnology 42: 81-102.

Mayr C, Lücke A, Stichler W et al. (2007b) Precipitation origin and evaporation of lakes in semi-arid Patagonia (Argentina) inferred from stable isotopes $\left(\delta \mathrm{O}^{18}, \delta \mathrm{H}^{2}\right)$. Journal of Hydrology 334: 53-63.

Mayr C, Wille M, Haberzettl T et al. (2007a) Holocene variability of the Southern Hemisphere westerlies in Argentinean Patagonia $\left(52^{\circ} \mathrm{S}\right)$. Quaternary Science Reviews 26: 579-584.

McCulloch RD, Fogwill CJ, Sugden DE et al. (2005) Chronology of the last glaciation in Central Strait of Magellan and Bahía Inútil, southernmost South America. Geografiska Annaler, Series A: Physical Geography 87: 289-312.

Meyers PA and Teranes JL (2001) Sediment organic matter. In: Last WM and Smol JP (eds) Tracking Environmental Change Using Lake Sediments: Physical and Geochemical Methods. Dordrecht: Kluwer Academic Publishers, 239-270.

Moy CM, Dunbar RB, Guilderson TP et al. (2011) A geochemical and sedimentary record of high southern latitude Holocene climate evolution from Lago Fagnano, Tierra del Fuego. Earth and Planetary Science Letters 302: 1-13.

Ohlendorf C, Gebhardt C, Hahn A et al. (2011) The PASADO core processing strategy - A proposed new protocol for sediment core treatment in multidisciplinary lake drilling projects. Sedimentary Geology 239: 104-115.

Paull CK, Matsumoto R, Wallace PJ et al. (1996) Gas hydrate sampling on the blake ridge and carolina rise sites 991-997. Proceedings of the Ocean Drilling Program, Initial Reports 164, pp. 99-174.

Rabassa J (2008) Late Cenozoic glaciations in Patagonia and Tierra del Fuego. In: Rabassa J (ed.) The Late Cenozoic of Patagonia and Tierra del Fuego. Elsevier, 151--204.

Round FE, Crawford RM and Mann DG (1990) The Diatoms. Biology and Morphology of the Genera. Cambridge: Cambridge University Press.

Rumrich U, Lange-Bertalot H and Rumrich M (2000) Iconographia Diatomologica - Diatomeen der Anden von Venezuela bis Patagonien Tierra del Fuego. A.R.G. Gantner Verlag K.G.

Stuiver M, Reimer P and Reimer R (2005) Calib 5.0. (WWW program and documentation at http://qcite.qub.ac.uk/handle/123456789/21845).

Tauxe L, Mullender TAT and Pick T (1996) Potbellies, wasp-waists, and superparamagnetism in magnetic hysteresis. Journal of Geophysical ResearchSolid Earth 101: 571-583.

Vuillemin A, Ariztegui D, Vasconcelos C et al. (2010) Establishing sampling procedures in lake cores for subsurface biosphere studies: Assessing in situ microbial activity. Scientific Drilling 10: 35-39.

Waldmann N, Ariztegui D, Anselmetti FS et al. (2009) Holocene climatic fluctuations and positioning of the Southern Hemisphere westerlies in Tierra del Fuego $\left(54^{\circ} \mathrm{S}\right)$, Patagonia. Journal of Quaternary Science 25: 1063-1075.

Wille M, Maidana NI, Schäbitz F et al. (2007) Vegetation and climate dynamics in southern South America: The microfossil record of Laguna Potrok Aike, Santa Cruz, Argentina. Review of Palaeobotany and Palynology 146: 234-246.

Zolitschka B, Anselmetti FS, Ariztegui D et al. (2009) The Laguna Potrok Aike Scientific Drilling Project PASADO (ICDP Expedition 5022). Scientific Drilling 8: 29-34.

Zolitschka B, Schäbitz F, Lücke A et al. (2006) Crater lakes of the Pali Aike Volcanic Field as key sites for paleoclimatic and paleoecological reconstructions in southern Patagonia, Argentina. Journal of South American Earth Sciences 21: 294-309. 